\title{
Effects of stopping smoking for 48 hours on oxygen availability from the blood: a study on pregnant women
}

\author{
JUDITH M DAVIES, I P LATTO, J G JONES, ANNE VEALE, C A J WARDROP
}

British Medical fournal, 1979, 2, 355-356

\section{Summary and conclusions}

The effects of stopping smoking for $\mathbf{4 8}$ hours on factors governing the availability of oxygen from the blood-that is, carboxyhaemoglobin (COHb), haemoglobin-oxygen $\left(\mathrm{HbO}_{2}\right)$ affinity, and haemoglobin concentration-were measured in women in the last trimester of pregnancy. Three groups were studied: smokers, smokers who stopped smoking for $\mathbf{4 8}$ hours, and non-smokers. The 22 smokers had higher initial COHb values and greater $\mathrm{HbO}_{2}$ affinity than the 10 non-smokers, but their total haemoglobin concentrations were also higher, so that their oxygen availability was not significantly reduced. In the 11 smokers who stopped the reduction in $\mathrm{COHb}$ and decrease in $\mathrm{HbO}_{2}$ affinity led to a significant increase of $8 \%$ in "available oxygen" in 48 hours.

Since even small improvements in oxygen delivery to the tissues may confer critical benefit to the fetus, particularly during labour or when exposed to general anaesthesia, smoking should be discouraged for $\mathbf{4 8}$ hours before elective deliveries. The same consideration might reasonably be applied to patients undergoing general anaesthesia for all elective operations.

\section{Introduction}

It is generally agreed that women who smoke should be advised to stop during pregnancy. Smoking results in the formation of carboxyhaemoglobin ( $\mathrm{COHb}$ ) and hence a reduction in functional haemoglobin. Also the affinity of haemoglobin for oxygen

\footnotetext{
University Hospital of Wales, and Welsh National School of Medicine, Cardiff CF4 4XW

JUDITH M DAVIES, FFARCS, consultant anaesthetist

I P LATTO, FFARCS, consultant anaesthetist

ANNE VEALE, BTECH, research assistant, department of haematology

C A J WARDROP, MRCP, MRCPATH, senior lecturer in haematology

University College, Cardiff CF1 1 XL

J G JONES, BPHARM, PHD, senior lecturer in biochemistry
}

is increased by carbon monoxide, thus impairing the release of oxygen-that is, a fall occurs in the tension of oxygen required to half-saturate the haemoglobin $\left(P_{50}\right.$ value). The availability of oxygen from the blood to the tissues in smokers is thus reduced.

The time available to hospital doctors to persuade patients to stop smoking may be limited. Most patients are admitted not more than two days before operation or labour. Since even a small improvement in oxygen availability might have important effects on the fetus, especially during the stress of anaesthesia and labour, we have measured changes in factors determining oxygen availability from the blood in a group of mothers who stopped smoking for 48 hours. We compare the findings with those in a group of mothers who continued to smoke and a group of non-smoking mothers.

\section{Patients and methods}

We studied 32 mothers during the last trimester of pregnancy. All gave informed consent. The smoking habits of those who smoked were documented, particularly details during the two days before the study. Of the 32 mothers, 11 continued to smoke during the 48 -hour study period (group 1), 11 agreed to stop smoking (group 2), and 10 were non-smokers (group 3). The three groups were similar in weight, age, parity, gestation, and clinical characteristics. Venous blood $(10 \mathrm{ml})$ and blood from the radial artery $(2 \mathrm{ml})$ were taken on two occasions 48 hours apart at midday.

"Available oxygen" is defined here as the amount available to the tissues per dl blood, as assessed from the measured arterial oxygen tension and with an assumed mixed venous tension of $2.67 \mathrm{kPa}$ $(20 \mathrm{~mm} \mathrm{Hg}) .{ }^{1}$ To avoid the influence on available oxygen of variations in haemoglobin concentration each patient's initial haemoglobin concentration was used in subsequent calculations. The blood was taken in heparinised plastic syringes and kept in iced water. With use of the IL 217 Blood Gas Laboratory (Instrumentation Laboratory, $\mathrm{UK}) \mathrm{COHb}$ was measured in venous blood and $\mathrm{pH}$ and pressure of carbon dioxide $\left(\mathrm{PCO}_{2}\right)$ in the arterial sample to permit calculation of base deficit. Haemoglobin-oxygen $\left(\mathrm{HbO}_{2}\right)$ affinity was derived from the simultaneously measured $\mathrm{HbO}_{2}$ saturation and oxygen pressure $\left(\mathrm{Po}_{2}\right)$ in fresh whole blood at oxygen saturations of about $45 \%, 50 \%$, and $55 \%$. The $\mathrm{P}_{50}$ standard $\left(\mathrm{pH} 7.4 ; \mathrm{PcO}_{2} 5.33 \mathrm{kPa}(40 \mathrm{~mm} \mathrm{Hg})\right.$ ) and $\mathbf{P}_{50}$ value in vivo (corrected for the calculated mixed venous $\mathrm{pH}$ and base deficit) were calculated as described. ${ }^{2}$ Red-cell 2,3-diphosphoglycerate (2,3-DPG) was measured in immediately deproteinised blood, according to Sigma Technical Bulletin No 35-UV (Sigma Laboratories, USA). 
TABLE I-Haematological variables in each group. (Results are means $\pm S D$ )

\begin{tabular}{|c|c|c|c|c|c|c|c|c|}
\hline & \multirow{2}{*}{$\begin{array}{c}\text { Haemo- } \\
\text { globin } \\
\text { (g/dl) }\end{array}$} & \multirow{2}{*}{$\begin{array}{l}\text { Venous } \\
\text { COHb }(\%)\end{array}$} & \multicolumn{2}{|c|}{$P_{50}(\mathrm{kPa})$} & \multirow{2}{*}{$\begin{array}{c}2,3-\mathrm{DPG} \\
(\mu \mathrm{mol} / \mathrm{g} \mathrm{Hb})\end{array}$} & \multirow{2}{*}{$\begin{array}{c}\text { "Available } \\
\text { oxygen," } \\
\text { corrected } \\
\text { for COHb } \\
(\mathrm{ml} / \mathrm{dl})\end{array}$} & \multirow{2}{*}{$\begin{array}{c}\text { Arterial } \\
\text { pH }\end{array}$} & \multirow{2}{*}{$\begin{array}{c}\text { Base } \\
\text { deficit } \\
(\mathrm{mmol} / \mathrm{l})\end{array}$} \\
\hline & & & Standard & In vivo & & & & \\
\hline $\begin{array}{ll}\text { Group } 1 \text { (smokers not stopping }(n=11)) & \left\{\begin{array}{l}\text { Initial } \\
\text { After } 48 \mathrm{~h}\end{array}\right. \\
\text { Initial } \\
\text { Group } 2 \text { (smokers stopping }(n=11)) \\
\text { After } 48 \mathrm{~h} \\
\text { Initial } \\
\text { After } 48 \mathrm{~h}\end{array}$ & $\begin{array}{l}12 \cdot 1 \pm 0.9 \\
11 \cdot 8 \pm 1 \cdot 2 \\
11 \cdot 4 \pm 0.5\end{array}$ & $\begin{array}{l}4 \cdot 6 \pm 2 \cdot 0 \\
4 \cdot 0 \pm 1 \cdot 4 \\
5 \cdot 1 \pm 1 \cdot 2 \\
1 \cdot 2 \pm 1 \cdot 2 \\
0 \cdot 9 \pm 1 \cdot 3 \\
0 \cdot 4+0 \cdot 8\end{array}$ & $\begin{array}{l}3 \cdot 10 \pm 0 \cdot 173 \\
3 \cdot 12 \pm 0 \cdot 133 \\
3 \cdot 16 \pm 0 \cdot 160 \\
3 \cdot 16 \pm 0 \cdot 160 \\
3 \cdot 27 \pm 0 \cdot 240 \\
3 \cdot 24 \pm 0 \cdot 187\end{array}$ & $\begin{array}{l}3 \cdot 12 \pm 0.200 \\
3 \cdot 17 \pm 0.093 \\
3 \cdot 13 \pm 0 \cdot 187 \\
3 \cdot 23 \pm 0 \cdot 200 \\
3 \cdot 32 \pm 0.280 \\
3 \cdot 33 \pm 0.253\end{array}$ & $\begin{array}{l}15 \cdot 0 \pm 2 \cdot 0 \\
15 \cdot 2 \pm 2 \cdot 3 \\
18 \cdot 7 \pm 3 \cdot 3 \\
17 \cdot 8 \pm 3 \cdot 7 \\
15 \cdot 6 \pm 3 \cdot 2 \\
15 \cdot 8 \pm 3 \cdot 2\end{array}$ & $\begin{array}{l}9 \cdot 1 \pm 1 \cdot 0 \\
9 \cdot 3 \pm 0 \cdot 8 \\
8 \cdot 8 \pm 1 \cdot 1 \\
9 \cdot 5 \pm 1 \cdot 2 \\
9 \cdot 5 \pm 1 \cdot 0 \\
9 \cdot 5 \pm 0 \cdot 8\end{array}$ & $\begin{array}{l}7 \cdot 44 \pm 0 \cdot 0 \\
7 \cdot 43 \pm 0 \cdot 0 \\
7 \cdot 45 \pm 0 \cdot 0 \\
7 \cdot 44 \pm 0 \cdot 0 \\
7 \cdot 43 \pm 0 \cdot 0 \\
7 \cdot 42 \pm 0 \cdot 0\end{array}$ & $\begin{array}{l}2 \cdot 15 \pm 1 \cdot 99 \\
3 \cdot 70 \pm 2 \cdot 23 \\
4 \cdot 14 \pm 1 \cdot 95 \\
3 \cdot 83 \pm 2 \cdot 4 \\
2 \cdot 95 \pm 1 \cdot 09 \\
2 \cdot 95: 1 \cdot 82\end{array}$ \\
\hline
\end{tabular}

Conversion: SI to traditional units- $\mathrm{P}_{50}: 1 \mathrm{kPa} \approx 7.5 \mathrm{~mm} \mathrm{Hg}$. 2, 3-DPG: $1 \mu \mathrm{mol} / \mathrm{g} \mathrm{Hb} \approx 261 \mu \mathrm{g} / \mathrm{g} \mathrm{Hb}$. Base deficit: $1 \mathrm{mmol} / 1=1 \mathrm{mEq} / 1$.

TABLE II-Differences in mean haematological variables between groups. (Results expressed $\pm S E$ )

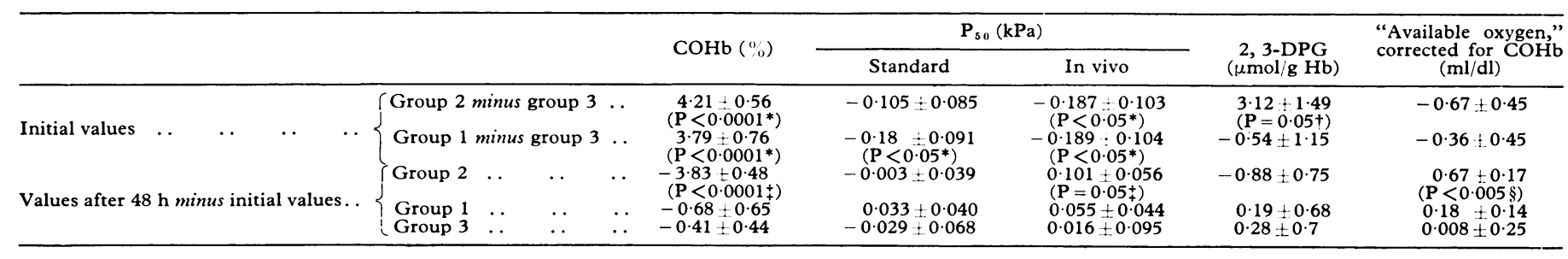

*One-tailed unpaired $t$ test. †Two-tailed unpaired $t$ test. $\quad$ †One-tailed paired $t$ test. $\quad$ \$Two-tailed paired $t$ test.

We used the one-tailed $t$ test to analyse changes that would occur in a predictable direction. In other analyses of differences we used the two-tailed $t$ test.

\section{Results}

Mothers who stopped smoking and those who did not stop smoked a mean of $43.9 \pm S D 13 \cdot 8$ and $44.9 \pm 12 \cdot 6$ cigarettes respectively during the 48 hours before the study. The mean intervals between the last cigarette and taking the initial samples in the two groups were $23 \cdot 6 \pm \mathrm{SD} 19 \cdot 1$ and $27 \cdot 3 \pm 19 \cdot 4$ minutes respectively.

Mothers who continued to smoke consumed significantly fewer cigarettes than usual $(30 \cdot 6 \pm 15 \cdot 2)$ during the study period $(\mathrm{P}<0.05)$. All patients had normal blood films, haemoglobin concentrations, and cell counts (measured on a Coulter model S).

Table I gives the findings in the three groups. The initial $\mathrm{COHb}$ values were much higher in the smoking than non-smoking mothers (tables I and II). Table II shows the differences in initial values between the three groups and the changes over 48 hours in each group.

\section{Discussion}

Despite the carboxyhaemaglobinaemia in the smokers in our series their increased total haemoglobin concentration gave an amount of functioning haemoglobin similar to that in nonsmokers. Stopping smoking for 48 hours caused the $\mathrm{COHb}$ value to fall almost to the value in non-smokers.

The initial $P_{50}$ value in vivo was significantly lower (by $0.187 \mathrm{kPa}(1.4 \mathrm{~mm} \mathrm{Hg}))$ in smokers than in non-smokers (table I). A similar difference $(0 \cdot 147 \mathrm{kPa}(1 \cdot 1 \mathrm{~mm} \mathrm{Hg}))$ was for nd in a study of male smokers and non-smokers. ${ }^{3}$ In our study stopping smoking increased the $P_{50}$ value in vivo by $0.101 \mathrm{kPa}(0.76 \mathrm{~mm} \mathrm{Hg})$. Smokers who did not stop reduced their consumption, which produced a rise of $0.055 \mathrm{kPa}(0.41 \mathrm{~mm}$ $\mathrm{Hg}$ ) in $P_{50}$ value in vivo. There was no significant change in the in-vivo $P_{50}$ value in non-smokers.

Smokers' initial amounts of "available oxygen" were not significantly different from those in non-smokers; the higher haemoglobin concentrations in smokers largely compensated for the adverse effects on oxygen transport of the $\mathrm{COHb}$ and increased $\mathrm{HbO}_{2}$ affinity. Other workers ${ }^{3}$ * also found higher haemoglobin concentrations in smokers than in non-smokers.

The initial 2, 3-DPG concentrations showed a different pattern from the other measurements. The initial concentration in smokers who stopped was higher than in non-smokers $(P=0.05$; tables I and II) and also higher than in smokers who did not stop ( $P<0.05)$. There may be a constitutional difference between women able to stop smoking and those unable to stop or this could be a chance observation, despite the statistical significance.

"Available oxygen" reflects the changes in $P_{50}$ in vivo and $\mathrm{COHb}$. There was a significant increase of $8 \%$ in "available oxygen" when mothers stopped smoking for 48 hours. This was due partly to a $4 \%$ increase in functioning haemoglobin after the loss of carbon monoxide and partly to the increase in $P_{50}$ in vivo. This increase in $\mathrm{P}_{50}$ in vivo must reflect the small changes in base deficit and $\mathrm{pH}$ over the two-day period; the $P_{50}$ standard did not change, presumably reflecting the opposing influences of a reduction in concentrations of both $\mathrm{COHb}$ and 2,3-DPG. Fetal hypoxia may occur during pregnancy and labour. ${ }^{5}$ An $8 \%$ increase in maternal "available oxygen" should result in a definite improvement in fetal oxygenation. This is important in conditions of acute stress and chronic placental insufficiency.

We recognise that allocation to the groups was not random. A randomised trial was not feasible, since many mothers cannot stop smoking. Nevertheless, the improved oxygen availability seen in group 2 may be expected in patients who can stop smoking, which is realistic in clinical conditions.

It is difficult to stop many mothers from smoking throughout pregnancy. Our study shows that improved oxygen transport should result from stopping smoking for 48 hours, which should be encouraged before elective deliveries. This conclusion could reasonably be applied to all elective surgical procedures performed under general anaesthesia, especially in patients with anaemia. ${ }^{6}$

We are grateful to Professor W W Mapleson for continuous advice and encouragement and to Drs Peter Elwood and Selwyn St Leger for epidemiological advice. We thank obstetric colleagues for permission to study their patients, and Mrs J Brown and Miss S Ball for typing the manuscript.

Requests for reprints should be sent to Dr J M Davies.

\section{References}

1 Jones, J G, et al, Scandinavian fournal of Haematology, 1979, 22, 77. 2 Gibby, O M, et al, Diabetologia, 1978, 15, 381.

3 Sagone, A L, Lawrence, T, and Balcerzac, S P, Blood, 1973, 41, 845.

4 Isager, H, and Hogerup, L, Scandinavian fournal of Haematology, 1971 8, 241.

5 British Medical Fournal, 1978, 1, 671.

6 Gillies, I D A, British fournal of Anaesthesia, 1974, 46, 589. 